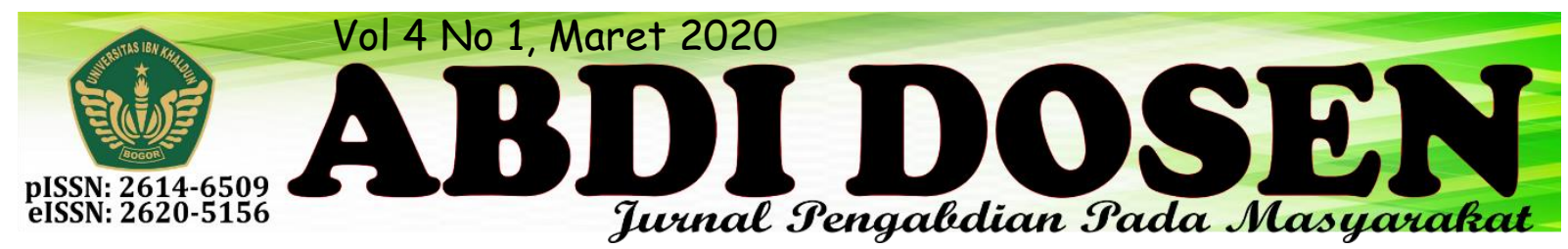

\title{
PEMBERDAYAAN MASYARAKAT DENGAN PROGRAM PANCA KARSA MELALUI KKN TERINTEGRITAS UNIVERSITAS IBN KHALDUN BOGOR TAHUN 2019
}

\author{
Oking Setia Priyatna ${ }^{1}, Z^{2}$ ahrotunnimah ${ }^{2}$ \\ oking@uika-bogor.ac.id ${ }^{1}$ \\ zahrotunnimah@yahoo.com ${ }^{2}$ \\ Dosen Fakultas Agama Islam¹, Dosen Fakultas Agama Islam²
}

\begin{abstract}
ABSTRAK
KKN Tematik Terintegrasi merupakan KKN yang fokus berorientasi pada bidang program tertentu sesuai dengan permasalahan masyarakat dan arah kebijakan dan arah kebijakan pengembangan sumber daya yang diselenggarakan pemerintah pada wilayah tertentu (Kabupaten/Kota). KKN memiliki tujuan untuk mencapai ekselerasi dan efektifitas program pemberdayaan sumber daya manusia yang ditandai dengan semakin baiknya kualitas kehidupan masyarakat, dan partisipasi masyarakat dalam program tersebut. Kegiatan KKN dibagi menjadi beberapa tahap yaitu survey dan observasi ke desa sasaran, workshop, penyuluhan, pendekatan sasaran program, realisasi program, monitoring dan evaluasi kegiatan. Pelaksanaan KKN dimulai dari 7 Agustus sampai dengan 5 September 2019 di Desa Cibeber II Kecamatan Leuwiliang Kabupaten Bogor. Program KKN kelompok 7 dan 8 di Des Cibeber II merupakan program yang lebih menekan kepada peningkatan kualitas sumber daya. Kegitan Fisik Kelompok $7 \& 8$ yaitu Pemberian dan pemasangan papan nama bangunan, renovasi masjid dan madrasah diniyah, pengadaan perlengkapan masjid dan Madrasah Diniyah, dan kegiatan non fisik kelompok 7 \& 8 antara lain Penyuluhan kesehatan (PHBS, Seks Education, Tensi, Cek Gula darah, Asam urat, tinggi badan dan berat badan) Kegiatan baca tulis hitung (Calistung) Belajar megajar disekolah, pengembangan UKM, pelaksanaan kegiatan madrasah, Seminar Ekonomi dan Hukum, Workshop Pendidikan, Lomba 17 Agustus, dan acara perpisahan KKN.
\end{abstract}

\section{Kata Kunci : Cibeber II, KKN, Program KKN}

\section{PENDAHULUAN}

Kuliah Kerja Nyata (KKN) Tematik Terintegrasi adalah KKN yang orientasi program terfokus pada bidang tertentu sesuai dengan permasalahan kemasyarakatan dan arah kebijakan pembangunan yang diselengarakan pemerintah pada Wilayah tertentu (Kabupaten/Kota). Dengan demikian bahwa KKN Tematik Terintegrasi berbasis problem solving untuk memecahkan masalah dengan tema tertentu sehingga kegiatan mahasiswa terfokus untuk mengatasi masalah tertentu sehingga kegiatan mahasiswa terfokus untuk mengatasi masalah tertentu dan untuk mencapai target tertentu sesuai dengan permasalahan.

\section{Analisis Situasi}

Berdasarkan hasil observasi dan analisis yang kelompok kami laksanakan di Desa Cibeber II Kecamatan Leuwiliang Kabupaten Bogor - Jawa Barat. Desa 
Cibeber II memiliki Luas wilayah 514.000.000 ha. Dengan batas wilayah sebagai berikut :

Sebelah Utara: Desa Cibeber I

Sebelah Selatan: Desa Pabangbon

Sebelah Timur: Desa Barengkok

Sebelah Barat: Desa Lewisadeng

Kecamatan Leuwisadeng

Desa Cibeber II adalah salah satu Des di Kecamatan Leuwiliang yang mempunyai luas wilayah $\pm 514.039 \mathrm{Km}^{2}$ jumlah penduduk Desa Cibeber II sebanyak 8.997 Jiwa yang terdiri dari 4.611 laki-laki dan 4.391 perempuan dengan jumlah Kepala Keluarga 2.812 KK sedangkan jumlah keluarga miskin (GAKIN) $1.582 \mathrm{KK}$ dengan peresentase $70 \%$ dari jumlah keluarga yang ada di Desa Cibeber II Kecamatan Leuwiliang.

Dilihat dari topografi dan konter tanah Desa Cibeber II scara umum berupa daratan dan hutan yang berada pada ketinggian antara $250 \mathrm{M}$ s/d $350 \mathrm{M}$ diatas permukaan laut dengan suhu rata-rata berkisaran antara $26^{\circ} \mathrm{s} / \mathrm{d} 27^{\circ}$ Celcius. Secara umum dapat dijelaskan bahwa penduduk keseluruhan Desa Cibeber II bermata pencaharian Petani, wiraswasta, buruh dan selebihnya mata pencaharian yang bervariasi.

Cukup rendahnya tingkat kesejahterahan masyarakat menjadi penyebab timbulnya beberapa masalah dengan beberapa bidang di Desa Cibeber II, diantaranya bidang ekonomi, kesehatan, lingkungan, pembangunan dan pendidikan. hal tersebut disebabkan oleh katidak berdayaan masyarakat desa karena kurangnya ilmu pengetahuan.

\section{Permasalahan yang dihadapi}

Dalam pelaksanaan program kerja Kuliah Kerja Nyata Tematik Terintegrasi sudah sangatlah umum jika mengalami permasalahan-permasalahan tak terkecuali selama pelaksanaan program. Setiap bidang memiliki masalah dengan tingkat kesulitan yang tentunya berbeda-beda. Adapun beberapa permasalahan yang terdapat di Desa Cibeber II, diantaranya:

1. Kurangnya perhatian orang tua terhadap pendidikan anaknya

2. Kurangnya pengembangan metode dan media pembelajaran yang dilakukan oleh guru pada saat mengajar.

3. Kurangnya sarana dan prasarana pendidikan TPA/TPQ di Desa Cibeber II

4. Kurangnya kesadaran masyarakat akan pentingnya kesehatan, sehingga menjadi penyebab utama timbulnya permasalahan kesehatan di masyarakat seperti penyakit kulit dan diare.

5. Meningkatnya permasalahan kenakalan remaja yang ditimbulkan dari pergaulan dan lingkungan luar yang bebas serta kurangnya perhatian orang tua untuk mengawasi anakanaknya.

6. Minimya pengetahuan masyarakat mengenai pasar modal syariah.

7. Kurangnya pengetahuan masyarakat dalam melakukan teknik pemasaran untuk memasarkan hasil usaha secara lebih luas.

8. Minimnya kepekaan anak-anak usia dini untuk berfikir menabung sejak dini.

9. Kurangnya kesadaran masyarakat akan pentingnya sarana dan prasarana tempat ibadah (masjid) untuk menunjang kegiatan ibadah umat islam.

10. Kurangnya kesadaran masyarakat mengenai tata cara mengurus Jenazah.

11. Kurangnya kesadaran masyarakat akan pentingnya surat-surat berharga mengenai surat kepemilikan tanah. 
12. Kurangnya antusias masyarakat dalam melaporkan pencatatan perkawinan secara resmi.

13. Minimnya sarana penerangan jalan di daerah Cibeber II terkhusus Dusun 4 Kampuang Angsana Kebun Teh.

14. Kurangnya kepekaan masyarakat untuk memberikan petunjuk jalan untuk mempermudah akses jalan.

\section{Solusi yang di tawarkan}

Dalam pelaksanaan program Kuliah Kerja Nyata Tematik Terintegrasi. Setelah memahami beberapa permasalahan yang terjadi di Desa Cibeber, maka kami menawarkan beberapa solusi untuk membantu memajukan Desa Cibeber II, solusi-solusi tersebut diantaranya:

1. Adanya program posko pintar (TPA Fathul Ilmi), program tersebut merupakan bimbingan belajar kepada anak-anak dalam memberikan pengetahuan tambahan kepada anakanak baik dalam pendidikan agama berupa bimbingan mengaji untuk membantu pembacaan huruf hijaiyah dan pengetahuan bahasa arab maupun pendidikan bahasa inggris serta pengetahuan umum.

2. Adanya program juru didik yang dilaksanakan disekolah untuk membantu dalam pelaksanaan belajar mengajar di SDN Sukamulya dan memberikan pengetahuan tambahan kepada anak-anak.

3. Adanya Program TBM (Taman Baca Masyarakat) yang didirikan di Madrasah Dinniyah Darussholihin desa Cibeber II, dengan tujuan untuk mempermudah anak-anak di Desa Cibeber II menambah ilmu dan wawasan baru diluar sekolah, serta meningkatkan minat baca anak-anak.

4. Adanya Workshop Pendidikan yang melibatkan para guru sebagai audiens, pada acara tesebut mengangkat materi mengenai meningkatkan mutu pedidikan melalui pengembangan media dan metode pembelajaran. Penyelenggaraan acara tersebut bertujuan untuk mengembangkan mutu pendidikan di desa Cibeber II melalui pengembangan media dan metode pembelajaran yang dilakukan oleh guru saat memberi pelajaran.

5. Adanya program penyuluhan kesehatan mengenai cuci tangan dan sikat gigi terhadap anak-anak sekolah dasar di SDN Sukamulya.

6. Adanya program penyuluhan kesehatan mengenai gizi seimbang disertai dengan cek kesehatan seperti gula darah, asam urat, tensi dan IMT (Indeks Masa Tubuh) terhadap warga.

7. Adanya program penyuluhan mengenai seks education yang dilaksanakan di sekolah menengah pertama SMPN 4 Leuwiliang.

8. Adanya Program pembuatan TOGA (Tanaman Obat Keluarga) yang dilaksakan di desa Cibeber II Kecamatan Leuwiliang.

9. Adanya program penyuluhan mengenai kewirausahaan sejak dini yang dilaksanakan di sekolah menengah pertama SMP 4 Leuwiliang desa Cibeber II.

10. Adanya program Seminar yang membahas mengenai Pasar Modal Syariah yang dilaksanakan di Kantor Kecamatan Leuwiliang Kabupaten Bogor.

11. Adanya program Cilbung (Cilik Menabung) dan kreatifitas menghias celengan yang dilaksanakan di SDN Sukamulya.

12. Adanya program penyuluhan mengenai pembentukan karakter, kegiatan ini berkesinambungan untuk mencegah 
atau meminimalisir mengenai kenalakan remaja yang terjadi dilingkungan SMPN 4 Leuwiliang.

13. Adanyanya program kegiatan berupa Seminar Hukum yang membahas mengenai surat kepemilikan tanah dan pencatatan perkawinan yang dilaksanakan di Kantor Kecamatan Leuwiliang.

14. Adanya program pemberdayaan lingkungan di Kp. Angsana Kebun Teh desa Cibeber II seperti renovasi masjid, penerangan jalan, dan pembuatan plang nama jalan Masjid dan Madrassah Dinniyah desa Cibeber II.

15. Adanya program pemberdayaan masyarakat di Kp. Angsana Kebun Teh desa Cibeber II seperti pelatihan pembuatan bross dan teknik pemasaran secara luas, serta pelaksanaan pelatihan pengurusan jenazah.

16. Adanya program dalam pelaksanaan perayaan HUT RI ke 74 di Kp. Pasir Honje, Kp Angsana Kebun Teh desa Cibeber II dan pelaksanaan perayaan HUT RI ke 74 di SDN Sukamulya.

\section{METODE PENGABDIAN}

Tahapan pelaksanaan untuk kegiatan ini sebagaimana terlihat pada bagan sebagai berikut :

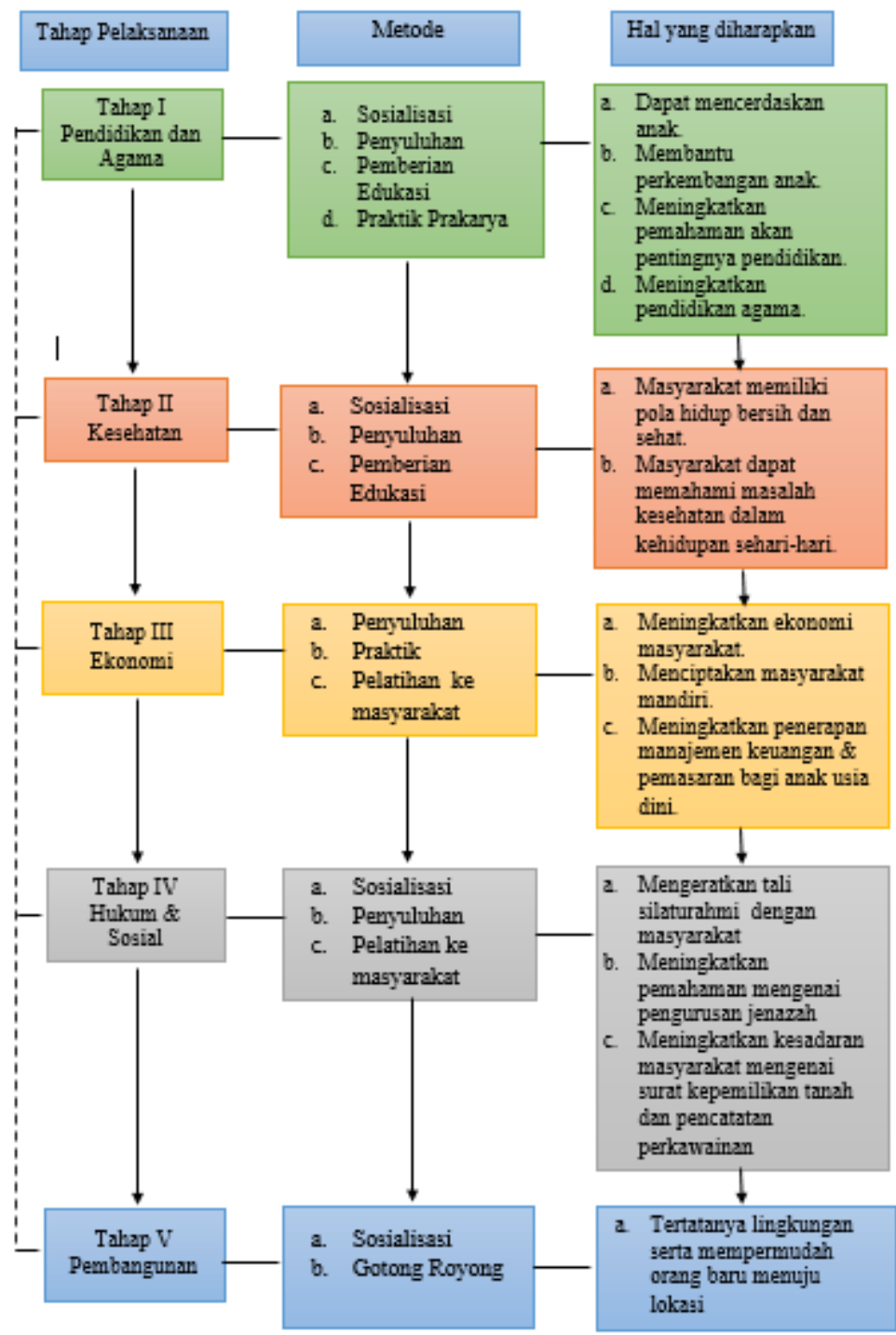




\section{Metode Pendekatan}

Ada beberapa pendekatan yang kami lakukan demi kelancaran program kerja selama satu bulan di Desa Cibeber II, pendekatan tersebut diantaranya :

1. Pendekatan pada Tokoh masyarakat

Pendekatan pada tokoh yang dimaksud adalah pendekatan dengan cara mendatangi para tokoh yang disegani di Kp. Angsana Kebun Teh. Seperti RT atau tokoh agama sekitar. Pendekatan ini bertujuan untuk mempermudah mahasiswa untuk mengajak masyarakat dengan bantuan para tokoh di lingkungan sekitar.

2. Pendekatan Religus

Pendekatan religius yang dimaksud adalah pendekatan dengan cara bergabung ke dalam majlis taklim atau pengajian ibu-ibu. Pendekatan religus ini dianggap perlu dilakukan di desa Cibeber II untuk mempermudah mahasiswa dalam membaur dengan masyarakat terutama ibu-ibu. Serta untuk menggali informasi dilingkungan sekitar.

3. Pendekatan Masyarakat

Pendekatan Masyarakat yang dimaksud adalah memahami kebiasaan warga desa Cibeber II dan mengikuti

\section{HASIL DAN PEMBAHASAN}

\section{Bidang Kesehatan Masyarakat}

\section{a. Penyuluan Sex Education}

Penyuluhan mengenai sex education merupakan program kerja yang dirancang khusus dalam memberikan pemahaman seputar anatomi dan fisiologi organ genetalis pria dan wanita beserta Penyakit Menular Seksual (PMS) yang dapat terjadi yang diakibatkan oleh perilaku penyimpangan seks atau perilaku seks beresiko. situasi di desa Cibeber II sehingga dapat mempermudah terealisasinya program kerja yang telah direncanakan.

4. Pendekatan Edukasi

Desa Cibeber II memiliki masyarakat yang memiliki latar belakang yang berbeda-beda. Tidak semua masyarakat mempunyai pengetahuan yang lebih modern dalam menjalankan kehidupan sehari-hari dilingkungannya. Maka dari itu pendekatan edukasi sangatlah di perlukan untuk mempermudah pendekatan dan pengenalan program kerja mahasiswa kepada warga sekitar.

\section{Langkah Evaluasi}

Evaluasi yang akan dilakukan terdiri dari :

1. Evaluasi proses yang terkait dengan perencanaan, pelaksanaan dan monitoring kegiatan. Evaluasi proses akan dilakukan di setiap kegiatan secara internal

2. Evaluasi hasil, yang akan dilakukan setelah kegiatan dilaksanakan.

3. Evaluasi dampak yang akan dilakukan 4 bulan setelah pelaksanaan pembinaan. Kita akan melakukan kunjungan kembali 2 bulan sekali untuk efektifitas kegiatan dan keberlangsungannya TPA Fathul Ilmi dan Taman Baca Masyarakat.

Tujuan:

- Memberikan pemahaman dan pengetahuan terkait anatomi dan fisiologi organ genetalis.

- Memberikan pengetahuan terkait penyakit menular seksual (PMS) dan cara pencegahannya.

- Dampak Bagi Siswa

Siswa dan siswi memiliki pengetahuan dan wawasan terkait edukasi seks dan bagaimana 
menyikapi permasalahan terkait hal yang berhubungan dengan hal tersebut.

\section{b. Dokter kecil ( Penyuluhan Cuci} Tangan Pakai Sabun (CTPS) dan sikat gigi )

Dokter kecil adalah suatu program yang merupakan bagian dari unit kesehatan sekolah (UKS) yang mana fungsinya adalah memberikan edukasi dan mendorong siswa di sekolah dasar untuk dapat berperilaku hidup bersih dan sehat. Program ini dilaksanakan atas analisis dan kajian yang menyeluruh terkait bagaimana perilaku kesehatan yang dilakukan siswa-siswi di SD Sukamulya Desa Cibeber II Kecamatan Leuwiliang, Kabupaten Bogor.

Tujuan :

- Menghidupkan kembali program unit kesehatan sekolah

- Memberikan pemahaman dan edukasi terkait PHBS khususnya perilaku cuci tangan dan gosok gigi

- Melaksanakan praktik langsung cuci tangan dan gosok gigi yang baik dan benar.

- Dampak Bagi Siswa

Program ini sangat dirasakan manfaatnya bagi siswa terutama siswa bisa melakukan cuci tangan dengan Gerakan yang benar serta gosokan gigi yang benar.

\section{c. Tanaman Obat Keluarga (TOGA)}

Tanaman obat keluarga merupakan tanaman hasil budidaya rumahan yang berkhasiat sebagai obat, tanaman obt pada hakikatnya adalah sebidang tanah yang digunakan untuk budidaya obat dalam rangka memenuhi keperluan keluarga akan obat-obatan. Dimana program ini kami rancang dengan melibatkan UPT Pengembangan Tanaman Obat Hambaro dan masyarakat
Kp. Angsana Kebon Teh RT 01/RW 06 Desa Cibeber II Kecamatan Leuwiliang Kabupaten Bogor. Sebagai upaya edukasi dan upaya promotif dalam mengajak masyarakat akan pentingnya menjaga kesehatan melalui pemanfaatan tanaman obat keluarga.

Tujuan :

- Membuat desain dan rancangan media tanam untuk tanaman obat keluarga dari bambu untuk dimanfaatkan masyarakat.

- Menyediakan bibit dan alat tanam serta uraian terkait fungsi tanaman yang disediakan.

- Dampak Bagi Masyarakat

Dampak yang diperoleh bagi masyarakat adalah masyarakat mengetahui jenis tanaman obat dan khasiatnya serta dapat memanfaatkan tanaman obat yang ditanam sebagai obat yang berkhasiat.

\section{d. Cek Kesehatan}

Merupakan program yang dilakukan sebagai upaya deteksi dini untuk mengurangi risiko penyakit atau memutuskan metode pengobatan yang paling efektif. Tes ini tidak termasuk dalam kategori diagnostik, tetapi digunakan untuk mengidentifikasi populasi yang diharuskan menjalani tes tambahan untuk menentukan ada atau tidaknya penyakit. Cek kesehatan yang dilakukan meliputi tes Indeks Massa Tubuh (IMT), tes tekanan darah, tes kadar asam urat, dan tes kadar gula darah. Cek kesehatan diadakan dua kali yang pertama diadakan di Kp. Angsana Kebon Teh RT 01/RW 06 dan yang kedua diadakan di aula kantor desa cibeber II bersamaan dengan program penyuluhan gizi seimbang.

Tujuan : 
- Untuk mengetahui prevalensi penyakit yang dominan diderita masyarakat desa cibeber II

- Untuk mengetahui kondisi kesehatan masyarakat desa cibeber II secara lebih terukur

- Dampak Bagi Masyarakat

Dampak yang dirasakan oleh masyarakat adalah masyarakat mengetahui penyakit apa yang kemungkinan diderita, apa tindakan yang harus dilakukan dan bagaimana pencegahannya.

\section{e. Penyuluhan Gizi Seimbang (ZIMBA)}

Program ini dibuat berdasarkan analisis kasus kesehatan yang menjadi masalah prioritas yang ada di desa cibeber II, dimana desa cibeber II merupakan desa yang termasuk ke dalam desa darurat stunting, permasalahan ini menjadi fokus utamabaik bagi pihak desa, para kader posyandu, bidan desa maupun puskesmas leuwiliang sebagai pusat layanan kesehatan primer setempat.

Stunting merupakan permasalahan terkait gizi yang dapat mendorong terjadinya gagal tumbuh dan gagal dalam perkembangan otak. Hal ini berkaitan dengan permasalahan nutrisi ibu ketika remaja, pra kehamilan, saat mengandung, dan pasca melahirkan, nutrisi yanga buruk pada 1000 HPK, tidak diberi asi ekslusif dan imunisasi, akses air bersih, rendahnya akses terhadap makanan bergizi dan kekurangan asupan energi dan protein.

Mengingat akses terhadap fasilitas pelayanan kesehatan di desa cibeber II yang terbilang jauh dan ketidak tersediaan sarana POLINDES (Posyandu Lintas Desa), POSKESDES (Pos Kesehatan Desa) atau PUSTU
(Puskesmas Pembantu) yang menyeabkan sulitnya petugas kesehatan untuk melakukan upaya intervensi beranjak dari permasalahan itulah kelompok 7 dan 8 KKN Tematik Terintegrasi UIKA Tahun 2019 mengadakan penyuluhan terkait permasalahan gizi yang mana pembahasan utamanya mengenai stunting. Dalam penyuluhan ini kami bekerjasama denagn UPT Puskesmas Leuwiliang, aparatur pemerintah desa cibeber II, bidan desa, kader posyandu, ibu hamil, dan ibu yang memiliki balita untuk ikut serta dan berperan aktif dalam penyelenggaraan program ini.

Tujuan :

- Memberikan edukasi kepada bidan desa, para kader, ibu hamil serta ibu yang memiliki balita terkait gizi seimbang, stunting, imunisasi, asi ekslusif.

- Dampak Bagi Masyarakat Masyarakat memiliki wawasan dan pengetahuan terkait stunting, gizi seimbang, asi ekslusif dan imunisasi, serta adanya rencana pembangunan Polindes di desa cibeber II.

\section{Bidang Pendidikan dan Agama}

\section{a. Posko Pintar}

Posko Pintar merupakan sebuah wadah tempat belajar ilmu agama dan juga pelajaran umum seperti bahasa Inggris, Bahasa Arab, matematika dan juga bercerita, Posko pintar ini merupakan cika bakal terbentuknya TPA Fathul Ilmi.

Tujuan :

- Untuk membantu anak-anak untuk mempelajari ilmu agama dan juga pelajaran umum lainnya seperti bahasa Inggris, Matematika dan bahasa Arab. 
- Dampak Bagi Masyarakat

Dengan adanya program ini masyarakat mempercayakan anakanaknya pada kami untuk belajar di posko karena sebelumnya tidak ada TPA jadi program ini sangat berdampak positif untuk masyarakat KP. Angsana Kebun teh terutama pada anak-anak.

b. Mengajar Dan Praktek Kesenian Kokoru di SDN Sukamulya

Program mengajar ini dilaksanakan untuk membantu guru dalam mengajar peserta didik dengan cara berbeda. Dengan menggunakan sekaligus pengenalan media dan metode pembelajaran yang belum pernah diajarkan. Membuat kokoru dari bahan dasar kertas dan pensil.

Tujuan :

- Mengenalkan media dan metode yang berbeda dalam pembelajaran dan membangkitkan kreativitas siswa dalam praktek kesenian.

- Dampak Bagi Masyarakat

Dampak dari program ini terkhususnya bagi sekolah adalah anak mendapatkan suasana baru dan dapat berkreativitas.

c. Mengajar di Madrasah Diniyyah Darussholihin

Mengajar pada dasarnya merupakan suatu usaha untuk menciptakan suatu kondisi atau sistem lingkungan yang endukung dan memungkinkan untuk berlangsungnya proses belajar. Mengajar adalah proses transfer pengetahuan yang diberikan seorang guru kepada murid dan dimengerti oleh anak didik tersebut, sehingga dapat pula dimanfaatkan bagi kehidupan kelak.

Tujuan :

- Untuk membantu guru madrasah Diniyyah Darussholihin dalam mengajar dan juga sebagai lading bagi para mahasiswa untuk mengaplikaskan ilmu yang dipunya. Meningkatkan semangat para siswa untuk belajar di Madrasah Diniyyah Darussholihin.

d. Pengadaan Fasilitas Madarasah Diniyyah Darussholihin

Fasilitas pendidikan adalah semua sarana dan prasarana yang mendukung dalam aktifitas pembelajaran sehingga dapat memberikan kenyamanan dalam proses belajar

Tujuan :

- Untuk melengkapi fasilitas madrasah dan memberikan Suasana belajar yang nyaman bagi siswa di sana.

- Dampak Bagi Masyrakat Para siswa dapat belajar dengan lebih nyaman, sehingga ilmu yang disampaikanmudah untuk di terima dan di amalkan kelak.

e. Workshop Pendidikan "Meningkatkan mutu pedidikan melalui pengembangan media dan metode pembelajaran"

Workshop pendidikan adalah ajang untuk memberikan ilmu pengetahuan dan wawasan pada guru yang ada dicibeber II mengenai bagaimana memilih dan mengembangan media dan metode pembelajaran yang sesuai dengan kebutuhan peserta didik.

Tujuan :

- Agar guru di desa cibeber II dapat bervariatif dalam menggunakan media dan metode pembelajaran.

- Dampak Bagi Masyarakat

Dampak untuk masyarakat adalah terkhusus para guru yang ada dicibeber 2 ialah dapat memanfaatkan workshop ini dengan menggali kembali media dan metode 
pembelajaran sesuai yang anak disik butuhkan.

\section{f. Taman Baca Masyarakat}

Taman Baca Masyarakat adalah perpustakaan kecil yang ditempatkan di madrasah dinniyah darussolihin yang dapat digunakan oleh masyarakat desa cibeber 2 guna membantu dalam pengetahuan dan meningkatkan minat baca pada masyarakat. Buku-buku yang kami dapatkan adalah buku umum, buku baca anak dan buku pelajaran. Yang mana kami peroleh buku tersebut sebagian dari hasil membeli dan sebagian lagi donatur dari Ruko Baca.

Tujuan :

- Meningkatkankan minat baca masyrakat dan menggali ilmu dari dibukanya program TBM ini.

- Dampak Bagi Masyarakat

Dampak program ini untuk masyarakat adalah dapat membantu masyarakat dalam mencari informasi melalu perpustakaan mini dan membangkitkan minat baca masyarakat.

\section{Bidang Ekonomi}

\section{a. Penyuluhan Menumbuhkan Jiwa Kewirausahaan Sejak Dini}

Penyuluhan membangun jiwa kewirausahaan sejak dini adalah ajang untuk memberikan ilmu pengetahuan dan wawasan kepada Siswa-siswi SMPN 4 Leuwiliang. Untuk bagaimana dapat mendapatkan uang dengan cara yang sederhana dan memberi edukasi bagaimana memanajemen keuangan dengan baik.

Tujuan :

- Meningkatkan keinginan untuk berwirausaha sejak dini dengan cara sederhana dan dapat mengatur keuangan secara mandiri.
- Dampak Bagi Masyarakat

Dampak program ini untuk adalah dapat membantu siswa-siswi untuk mengetahui bagaimana cara untuk melakukan kewirausahaan dengan cara sederhana dan modal yang seminim mungkin.

\section{b. Teknik Pemasaran Produk}

Kegiatan ini laksanakan beriringan dengan dilaksanakannya program kegiatan pelatihan pembuatan bross. Teknik Pemasaran Produk ini dilakukan dengan tujuan memberi edukasi kepada masyarakat untuk mengetahui bagaimana teknik-teknik pemasaran secara luas dan pemasaran dalam jumlah besar.

Tujuan :

- Meningkatkan pengetahuan masyarakat mengenai teknik pemasaran yang baik dan terorganisasi dengan baik.

- Dampak Bagi Masyarakat

Dampak yang dirasakan oleh masyarakat adalah masyarakat mengetahui bagaimana teknik pemasaran yang baik dan terorganisir.

\section{c. Seminar Ekonomi "Edukasi Pasar}

\section{Modal Syaria”}

Edukasi tentang Pasar Modal Syariah merupakan suatu media pengembangan minat keuangan bagi masyarakat umum. Kegiatan ini merupakan sebuah usulan dari Kelompok Studi Pasar Modal (KSPM) Universitas Ibnu Khaldun Bogor untuk diadakan di Kecamatan Leuwiliang dan akan melibatkan mahasiswa Universitas Ibnu Khaldun yang sedang menjalani Kuliah Kerja Nyata (KKN) sebagai panitia acara Edukasi tentang Pasar Modal Syariah. Mengingat pentingnya investasi bagi masyarakat Indonesia, maka kegiatan ini sangat perlu untuk 
diadakan supaya masyarakat bisa memahami investasi yang benar menurut syariat dan memiliki jaminan hukum dari Negara. Manfaat kegiatan dalam hubungan ekternal adalah memberikan wawasan dan pengetahuan kepada masyarakat tentang investasi di pasar modal syariah dan manfaat dalam bidang akademis yaitu menumbuhkan jiwa kompetitif melalui pengetahuan ekonomi, menumbuhkan kesadaran akan pentingnya berinvestasi dan memberi pengetahuan mengenai investasi di pasar modal syariah untuk masyarakat. Sasaran pada kegiatan ini adalah Masyarakat Umum, khususnya para aparatur kecamatan, kepala desa dan masyarakat usia produktif. Dan peserta pada kegiatan ini adalah Aparatur Kecamatan Leuwiliang, Kepala Desa yang ada di Kecamatan Leuwiliang dan Masyarakat Umum.

Tujuan :

- Untuk mengedukasi masyarakat dan lebih memperkenalkan pasar modal syariah, apa manfaat dan bagiaman pelaksanaanya.

- Dampak Bagi Masyarakat

Masyarakat lebih mengetahui secara detail mengenai apa yang dimaksud dengan pasar modal syariah dan apa perbedaan antara pasar modal syariah dan pasar modal konvensiona.

\section{d. Penyuluhan Cilik Menabung} (Cilbung) dan Menghias Celegan

Kegiatan ini merupakan salah satu cara untuk menanamkan rasa gemar menabung pada anak-anak dengan mengedukasi anak agar dapat mengelola keuangan dengan baik secara sederhana. Manfaat dari kegiatan ini adalah untuk memberikan pemahaman kepada anakanak bahwa menabung sejak dini sangatlah bermanfaat bagi masa depan dan melatih menabung bagi anak-anak akan memberikan dampak positif bagi kehidupannya. Kegiatan ini dilakukan dengan mengajak anak-anak untuk menghias celengan yang bertujuan untuk meningkatkan kreatifitas anak-anak. Sasaran yang ingin dicapai adalah timbulnya kesadaran anak-anak untuk dapat menyisihkan sebagian dari uang yang mereka miliki agar dapat ditabung di celengan. Sedangkan sasaran kegiatan ini yaitu siswa-siswi SD Negeri Sukamulya.

Tujuan :

- Tujuan dari kegiatan ini adalah mensosialisasikan tentang pentingnya menabung sejak usia dini dan menjelaskan manfaat menabung sehingga dapat memotivasi anak-anak untuk menabung.

- Dampak Bagi Masyarakat

Dampak dari program ini terkhususnya bagi sekolah adalah anak mendapatkan suasana baru dan dapat berkreativitas.

\section{Hukum dan Sosial}

\section{a. Seminar Hukum "Surat Kepemilikan Tanah dan Pencatatan Perkawinan"}

Kegiatan ini dilaksanakan secara sharing masalah hukum yang ada dan bagaimana cara penyelesaiannya dalam permasalahan atas Surat Kepemilikan Tanah dan Pencatatan Perkawinan

Tujuan :

- Untuk memberikan edukasi mengenai surat - surat kepemilikan tanah dan mengenai pencatatan perkawinan.

- Dampak Bagi Masyarakat Dampak Penyuluhan Hukum ini sangat berguna bagi masyarakat yang hadir, dikarenakan di beberapa desa di kecamatan Leuwiliang masih banyak warga yang buta akan hukum 
atau belum mengetahui mengenai aturan tentang surat kepemilikan tanah dan pencatatan perkawinan yang sangat penting untuk masyarakan sebagai landasan hukum yang kuat. dengan adanya penyuluhan tersebut masyarakat dapat teredukasi dan sedikit mengerti mengenai hukum.

b. Penyuluhan Hukum "Kenakalan Remaja dan Pembentuka Karakter"

Kegiatan ini dilaksanakan untuk mengatasi kenakalan remaja yang ada disekitar lingkungan sekolah. Kegiatan ini dilaksanakan bertempat SMPN 4 Leuwiliang, penyuluhan tersebut didukung dengan antusias oleh jajaran guru- guru di sekolah tersebut.

Tujuan :

- Memberikan pemahaman dan pengetahuan bagi anak-anak agar memiliki pengetahuan tentang bahayanya pergaulan bebas dan mengerti dalam pencegahan terjadinya pergaulan remaja yang negative.

- Memberikan arahan kepada anak usia remaja bagaimana dalam membentuk karakter diri sendiri dengan baik dan menjalankan kegiatan positif.

- Dampak Bagi Masyarakat

Dapat mengetahui apa saja bahaya pergaulan bebas dan mengetahui bagaimana cara pencegahan terjadinya pergaulan remaja yang negative.

\section{c. Pelatihan Pembuat Bross}

Kegiataan ini dilakukan untuk bimbingan kepada masyarakat mengenai kerajinan berwirausaha dengan menghasilkan produk sendiri dan dibuat dengan bahan bekas. Program ini bertujuan untuk mengembangkan tingkat pendapatan per individu dengan cara pembuatan bross dan di pasarkan secara luas. Serta untuk mengurangi nya tingkat pengangguran pada anak remaja yaitu diberikan bekal pendidikan dan keterampilan.

Tujuan :

- Untuk meningkatkan kreatifitas dan meningkatkan pendapatan sosial perindividu serta mengurangi angka pengangguran pada usia remaja.

- Dampak Bagi Masyarakat Masyarakat mendaptkan ilmu dan keterampilan dalam membuat bros.

\section{d. Pemakmuran Masjid}

Masjid merupakan pusat kegiatan kaum muslimin merancang masa depannya, baik dari segi agama, ekonomi, politik, sosia dan seluruh sendi kehidupan, sebagimana para pendahulunya memfungsikan masjid secara maksimal. Dalam kegiatan pemakmuran masjid ini terdapat beberapa aspek yang diangkat yaitu :

1. Renovasi Masjid

2. Pelatihan Pengurusan Jenazah

3. Pengadaan Fasilitas Masjid seperti Keranda, Al-Quran, Sarung dan Mukena.

Tujuan :

- Melengkapi fasilitas masjid yang sudah ada dan memperlancar pelaksanaan program kegiatan masjid.

- Manfaat Bagi Masyarakat

Menghidupkan Masjid dengan kegiatan-kegiatan keagamaan,

Meningkatkan kekompakan pemuda islam sehingga agama islam menjadi kuat.

\section{Bidang Teknik dan Pembangunan.}

\section{a. Penerangan jalan menuju sumber} mata air

Air merupakan sumber kehidupan bagi manusia. Begitu juga dengan 
masyarakat di Kp. Angasa Kebon Teh RT 01 RW 06 Desa Cibeber II Kecamatan Leuwiliang Kabupaten Bogor, mereka masih mengandalkan sumber mata air langsung dari pegunungan untuk memenuhi kebutuhan-kebutuhan rumah tangga seperti mandi, mencuci, memasak, dan lain sebagainya. Namun akses jalan menuju sumber mata air langsung ini melalui perkebunan dan belum mendapatkan penerangan jalan, hal ini menjadi suatu permasalahan bagi masyarakat itu sendiri. Maka dari itu, dibuatkan penerangan jalan menuju sumber mata air untuk menerangi jalan ketika dimalam hari.

Penerangan jalan menuju mata air dilakukan dibeberapa titik. Dengan memanfaatkan sumber listrik dari mesjid dekat dengan sumber air, kami membuat 4 titik penerangan jalan ditempatkan pada dahan pohon besar pada jalur menuju sumber mata air.

Tujuan :

- Untuk mempermudah warga sekitar untuk mengambil dimalam hari. Agar tidak terlalu gelap dan membahayakan.

- Dampak Bagi Masyarakat Mempermudah akses jalan menjuju mata air yang gelap dan tempatnya harus menuruni banyak anak tangga.

\section{KESIMPULAN}

Berdasarkan hasil kegiatan pengamatan, maupun pelaksanaan program kerja KKN yang telah direncakan, disusun dan dilaksanakan. Maka kelompok 7 dan 8 KKN UNIVERSITAS IBN KHALDUN BOGOR 2019 di Desa Cibeber II Kecamatan Leuwiliang mengambil beberapa kesimpulan yaitu :
Dengan adanya lampu jalan menuju mata air warga tidak perlu lagi khawatir akan gelap nya jalan.

\section{b. Pembuatan Plang}

Pada dasarnya rambu peringatan dan petunjuk arah sangat di perlukan dilingkungan masyarakat, karna untuk memenuhi prasarana yang ditujukan untuk pemberitahu letak dan peringatan bagi kesalamat warga sekitar. Lalu memberi kenyamanan dan kesadaran bagi warga desa dan pengguna jalan . Merencanakan program kerja pembuatan plang peringatan dan petunjuk arah di Desa Cibeber II khusunys di Kp. Angsana Kebun Teh ini sangatlah tepat karana minimnya prasarana di daerah desa Cibeber II. Adapun plang yang dibuat sebagai berikut :

1. Penerangan jalan menuju sumber mata air

2. Petunjuk jalan menuju mesjid jami nurul huda

3. Petunjuk jalan menuju madrasah diniyah darussolihin

4. Plang lokasi madrasah

Tujuan :

- Memberi kenyamanan dan kesadaran bagi warga desa dan pengguna jalan

- Dampak Bagi Masyarakat Mempermudah bagi para pendatang untuk mengetahui tata letak di daerah tersebut.

1. Keberhasilan KKN tidak lepas dari kerjasama antara mahasiswa dengan perangkat desa, masyarakat, serta semua pihak yang membantu mendukung terlaksananya kegiatan $\mathrm{KKN}$, tanpa adanya kerja sama yang baik, maka program KKN tidak akan berjalan dengan baik. 
2. Dengan adanya mahasiswa $\mathrm{KKN}$ masyarakat terbantu dengan bertambahnya informasi dan ilmu pengetahuan yang mereka peroleh dari mahasiswa KKN.

3. Antusiasnya masyarakat dengan kehadiran mahasiswa KKN yang dapat membantu mencari solusi dari beberapa kendala yang ada di daerah tersebut.

4. Masih kurangnya keperdulian masyarakat desa terhadap lingkungan sekitar, dan kurangnya antusias dalam pelaksanaan pemakmuran masjid atau tempat peribadatan.

5. Potensi desa Cibeber II cukup baik, hanya saja kurang maksimalnya pengembangan potensi desa tersebut oleh perangkat desa dan masyarakat sekitar. Ada beberapa hal yang kurang memuaskan antara lain :

\section{REFERENSI}

LPPM: Universitas Ibn Khaldun Bogor (2019), Petunjuk Pelaksanaan Terintegrasi 2019

M.Shabir, Khairul Anwar, Agung Maulana (2017) Pemberdayaan Masyarakat melalui Peningkatan Mutu Pendidikan Dan Kesehatan Di Desa Bojong Sempu, Kecamatan Parung a. Kurangnya kerjasama yang baik antara masyarakat dengan perangkat desa serta instansi terkait guna memperlancar pembangunan desa.

b. Kurangnya keterbukaan aparat desa terhadap masyarakat, maupun kuranya hubungan komunikasi yang baik dengan warganya terkhusus pada daerah Kp. Angasna Kebun teh

Dengan demikian, hasil kesimpulan diatas menunjukan bahwa secara garis besar program KKN kelompok 7 dan 8 dapat dikatakan sukses dan lancar meskipun ada beberapa kendala baik dari pihak mahasiswa maupaun pihak perangkat desa di desa Cibeber II namun itu tidak berpengaruh terhadap program yang telah direncanakan.

Kabupaten Bogor, Jurnal Abdi Dosen, Vol. 01, No. 01, 2017.

Annisatul Fathimah, Utari Agnesia, Ridho Abdul S (2019) Pemberdayaan Masyarakat Melalui Peningkatan Mutu Pendidikan, Ekonomi Dan Kesehatan Studi Kasus Desa Cibeber II, Jurnal Abdi Dosen, Vol. 03, No. 01, 2019. 